\title{
A histological and histochemical study of the oesophagus and oesogaster of the Senegal sole, Solea senegalensis
}

\author{
J.M. Arellano', V. Storch ${ }^{2}$, and C. Sarasquete ${ }^{1}$
}

'Instituto de Ciencias Marinas de Andalucía, CSIC, Polígono Río San Pedro, Apdo Oficial, 11510, Puerto Real, Cádiz, Spain; ${ }^{2}$ Department of Zoology I, Im Neuenheimer Feld 230, D-6900. University of Heidelberg, Heidelberg, Germany

Accepted: 6/4/01

Keywords: ultrastructure, oesogaster, oesophagus, Senegal sole

\section{SUMMARY}

A histological and histochemical study was performed in the buccal cavity and papillae, which were around the teeth, as well as in the oesophagus and oesogaster of the Senegal sole, Solea senegalensis adult specimens.

The oesophagus and oesogaster were made up of four distinct layers: mucosa, submucosa, muscular and serous. Two morphological types of epithelial cells were distinguishable in the oesophageal mucosa: the more numerous type cells possessed an electron-dense cytoplasm, whereas the cytoplasm was electron-clear in the other cells. Mucussecreting cells were the dominant feature of the epithelium throughout the oesophagus. These goblet cells were filled with numerous mucous droplets of low electron-density. The oesophagus was devoid of taste buds.

In the oesogaster mucosa, three types of cells were distinguished: dark, rodlet and light epithelial cells. Dark epithelial cells showed different characteristics from that in the oesophagus: the nucleus was irregular with an electron-dense hyaloplasm, the cytoplasm had a scarce smooth and granular endoplasmic reticulum; a Golgi apparatus consisted of four parallel cisternae, dense granules without membrane, lysosomes and numerous mitochondria. The rodlet cells were elongated, contained rod-like structures and were surrounded by an electron-dense capsule-like structure. The bulk of the rodlet cell was composed of up to 20 extended rodlet units. Light epithelial cells of the oesogaster had the same characteristics as those observed in the oesophagus and contained numerous mitochondria with a dense matrix, abundant smooth endoplasmic reticulum and numerous vesicles.

In the goblet cells of the papillae, sulfomucin was recognised, since they showed alcianophilia (alcian blue $\mathrm{pH} 1.0$ and 0.5 ). These cells were negative to protein reaction (bromophenol blue) and contained -S-S- and SH groups. Enzymatic activities (alkaline phosphatase, acid phosphatase, ATPase ( $\mathrm{pH} 7.2$ and 9.4) and lipid reactions were negative in the goblet cells of the buccal cavity.

Epithelial cells of oesophagus contained a weak presence of acid and neutral mucopolysaccharides. Oesophageal goblet cells contained carboxylated, sulphated (weakly and strongly ionised) mucosubstances and sialic acid. Most goblet cells did not contain proteins and presented disulphide (-S-S-) and sulphydril (-SH) groups. Proteins in general, and in particular those rich in lysine, tyrosine and arginine were present in the 
epithelium, lamina propria, submucosa and muscular layer of the oesophagus.

Lipids in general and phospholipids were observed in the oesophageal epithelium while unsaturated, acid and neutral lipids were not observed. The lamina propria and submucosa contained a weak presence of phospholipids and unsaturated lipids. Acid phosphatase and ATPase ( $\mathrm{pH}$ 7.2) activities were observed in the lamina propria, submucosa and muscular regions, while ATPase ( $\mathrm{pH}$ 9.2) activity was weak in these areas. ATPase activity $(\mathrm{pH} 7.2$ and 9.5) was very weak in the epithelium. Oesophageal goblet cells were negative to lipid and enzymatic reactions.

\section{INTRODUCTION}

The anatomy and histology of the alimentary tract of teleostean fish have been described for many species (see Barrington, 1957; Khana and Mehrotra, 1971; Vegas-Velez, 1972; Kapoor et al., 1975 for reviews) although there are few studies dealing with the ultrastructure of the digestive tract. Compared to mammals, the teleost digestive tract is histologically simpler, probably because it is so easy to provide an aqueous vehicle for the digestive products and also because, at least in some species, the rate of digestion can be slow, and less complex digestive glands and a less well-developed muscular apparatus are needed (Ferguson, 1995).

The oral cavity and pharynx in most teleostean fish are lined by a thin stratified squamous epithelium containing abundant mucus-secreting cells. Fungiform and filiform papillae may be found, and many species have teeth, which vary greatly in shape. The oesophagus is short and thick walled; the muscularis is comprised of interweaving skeletal muscle fibers that may extend as far as the stomach. The stratified cuboidal or columnar epithelium may be ciliated and contains numerous goblet cells and occasionally taste buds. In addition, multicellular serous or cardiac glands may be found subsequently. The mucosa is thrown into longitudinal folds that end at the stomach, giving way to rugae. The serosa contains prominent nerve fibers of the vagus (Morrison, 1987; Amin et al., 1994).

Some portions of the digestive tract of marine teleosts, specifically the oesophagus and the intestine, are involved in osmoregulation (Kirsch and Laurent, 1975; Hirano and Mayer-Gostan, 1976;
Ruiter et al., 1985; Cataldi et al., 1988a; Cataldi et al., 1988b; Ciccotti et al., 1993). The main osmoregulatory tissue, the gills (Karnaky et al., 1977; Zaccone, et al., 1984), as well as the digestive tract, participates directly in this process (Mancera et al., 1993).

The aim of this work was to study the morphology, ultrastructure, as well as enzymatic activity-, lipid-, carbohydrate- and protein distribution in the oesophagus and oesogaster of the Senegal sole, Solea senegalensis, as a complement to existing studies on their nutritional physiology, since this flatfish is an excellent economical and commercial species for culture and exploitation in different countries.

\section{MATERIALS AND METHODS}

Adult specimens of the Senegal sole, Solea senegalensis (mean body weight 370-430 g, total length ranging from $20-30 \mathrm{~cm}$ ) were obtained from "Cupimar, S.A" fisheries (San Fernando, Cádiz, Spain). Fish were maintained in tanks of 2000 L in the Andalucía Marine Science Institute (CSIC) until their utilisation. Specimens were anaesthetised with benzocaine, $50 \mathrm{mg} / \mathrm{L}$, and the abdominal cavity was dissected.

For light-microscopic studies (carbohydrates and proteins), small samples of buccal cavity, papillae, oesophagus and oesogaster were fixed by immersion in Bouin's fluid for $24 \mathrm{~h}$. After dehydration in graded concentrations of ethanol, samples were embedded in paraffin wax. Sections of 6-8 $\mu \mathrm{m}$ thickness were stained with haematoxylin-eosin and haematoxylin-VOF (Gutiérrez, 1967). Argentic impregnation (kit Bio-Optica milano s.p.a.) was also performed for determining the collagen fibers. Lipid and enzymes were used in unfixed samples from cryostat (Cryocut-E). Histochemical techniques of carbohydrates, proteins, lipids and enzymatic activities are shown in Tables I and II.

\section{Scanning electron microscopy (SEM)}

Oesophagus samples for scanning electron microscopy were fixed in $4 \%$ glutaraldehyde in (0.1M) Na-cacodylate buffer ( $\mathrm{pH}$ 7.2) dehydrated through ethanol series, critical point dried with liquid $\mathrm{CO}_{2}$, coated with gold, and viewed in a Hitachi S 570 scanning electron microscope. 
Table I

Histochemical reactions used to detect carbohydrates and proteins. Staining techniques for carbohydrates and proteins were taken from monographs by Martoja and Martoja-Pierson (1970) and Pearse (1985)

Staining techniques

Carbohydrates

Periodic acid-Schiff (PAS)

Diastase-PAS

Alcian Blue (AB) pH 2.5

Alcian Blue (AB) $\mathrm{pH}$ 2.5/PAS

$\mathrm{AB} \mathrm{pH} 1.0$

$\mathrm{AB} \mathrm{pH} 0.5$

Neuraminidase or hydrochloric acid

hydrolysis $-\mathrm{AB} \mathrm{pH} 2.5$

Esterification- $\mathrm{AB} \mathrm{pH} 2.5$

Esterification-Saponification-AB pH 2.5

Esterification- $\mathrm{AB}$ pH 1.0

Esterification -Saponification-AB pH 1.0

Esterification- $\mathrm{AB} \mathrm{pH} 0.5$

Esterification-Saponification-AB pH 0.5

\section{Proteins}

Bromophenol blue

Ninhydrin-Schiff

Thioglycolate-potassium ferricyanide (Fe III)

1,2 Naphtoquinone-4-sulphonic acid, sodium salt

Hg sulphate-sulphuric acid sodic nitrate

Ferric ferricyanide (Fe III)

p-Dimethylaminobenzaldehyde

\section{Functions and/or components demonstrated}

Glycogen, neutral mucosubstances and/or glycoconjugates Glycogen

Carboxyl-rich glycoconjugates (sulphated or not)

Neutral and/or acid rich glycoproteins

Sulphated glycoconjugates (weakly ionised)

Sulphated glycoconjugates (strongly ionised)

Cleavage of $\mathrm{C}_{4}$ not acetylated sialic acid

Blockage of carboxylated and sulphated groups

Reactivation of carboxylated groups

Blockage of sulphated groups (weakly ionised)

Unreactivation of sulphated groups (weakly ionised)

Blockage of sulphated groups (strongly ionised)

Unreactivation of sulphated groups (strongly ionised)

Proteins in general

Proteins rich in lysine (-NH2 groups)

Proteins rich in cystine (-S-S- groups)

Proteins rich in arginine

Proteins rich in tyrosine

Proteins rich in cysteine (-SH- groups)

Proteins rich in tryptophan

\section{Transmission electron microscopy (TEM)}

Small pieces of oesophagus and oesogaster were fixed for $2 \mathrm{~h}$ in cold cacodylate-buffered, $2.5 \% \mathrm{glu}-$ taraldehyde at $\mathrm{pH} 7.2$ (with sucrose $6 \%$ ), rinsed several times in buffer (without sucrose) and postfixed with $1 \% \mathrm{OsO}_{4}$ in $0.1 \mathrm{M}$ cacodylate buffer (rinsed several times in buffer). The samples were dehydrated in a graded series of acetone and embedded in Spurr's medium. Ultrathin sections of 60 to 80 $\mathrm{nm}$ thickness (Reichert Jung ultramicrotome) were stained with uranyl acetate and lead citrate prior to examination under the electron microscope (Zeiss EM 9S2).

\section{RESULTS}

The alimentary canal of the Senegal sole, Solea senegalensis is formed by the buccal-pharynx cavity, oesophagus, stomach and intestine (Fig. 1). In
Table II

Histochemical reactions used to detect lipids and enzymes. Staining techniques for lipids and enzymes were taken from monographs by Pearse (1985) and Bancroft and Stevens (1990)

\begin{tabular}{|c|c|}
\hline Staining techniques & $\begin{array}{l}\text { Functions and/or } \\
\text { components demonstrated }\end{array}$ \\
\hline Oil Red 0 & Neutral lipids \\
\hline Br- Oil Red 0 & Unsaturated lipids \\
\hline Fe (III) Haematoxylin & Phospholipids \\
\hline Sudan Black B & Neutral general \\
\hline Nile Blue & Neutral and acidic lipids \\
\hline Alkaline phosphatase & Alkaline phosphatase activity \\
\hline Acid phosphatase & Acid phosphatase activity \\
\hline ATPase (pH 7.2) & ATPase (pH 7.2) activity \\
\hline ATPase (pH 9.4) & ATPase (pH 9.4) activity \\
\hline
\end{tabular}



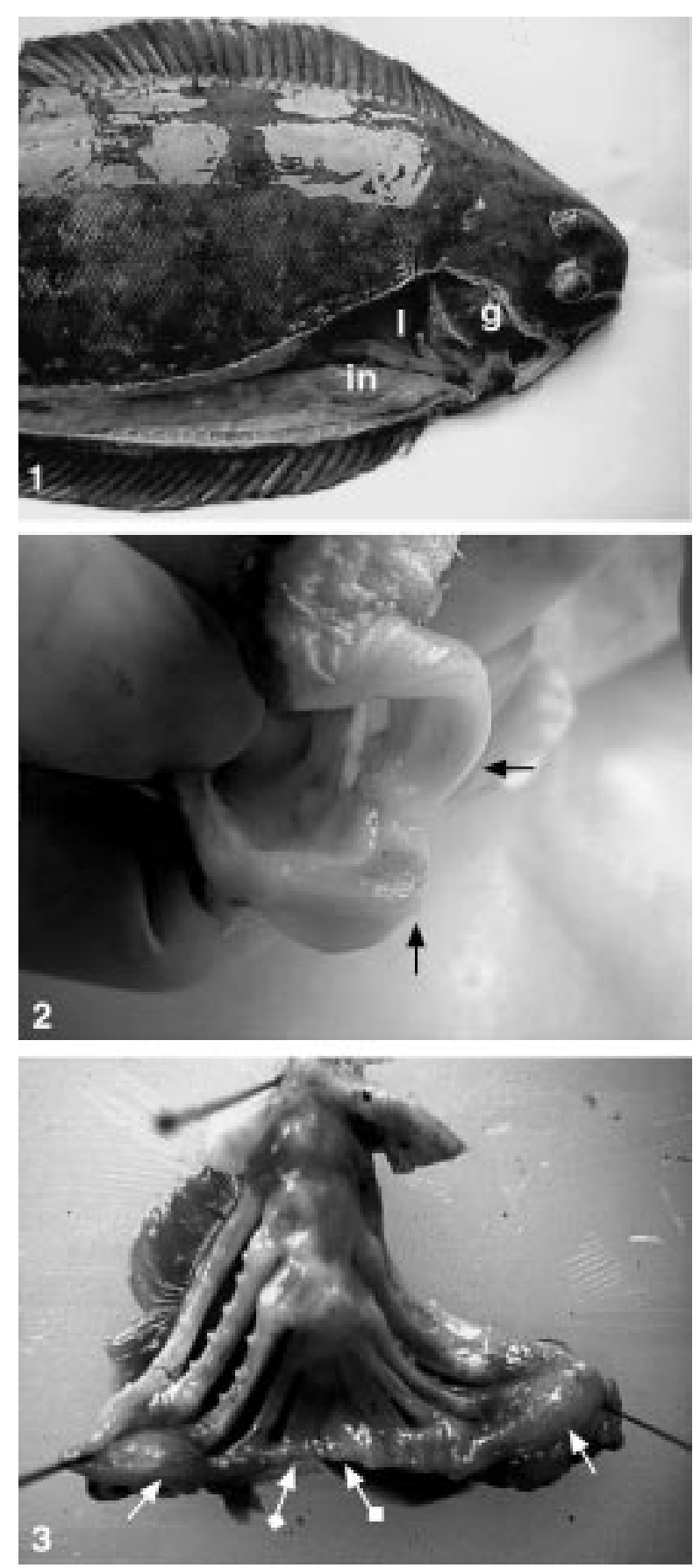

Figs. 1/3 - (1)Intestine (in), liver (1) and gills (g) of Solea senegalensis. (2)Buccal papillae $(\rightarrow)$. (3)Gill papillae $(\rightarrow)$ in the arch gills and oesophagus papillae $(\bullet)$.

the buccal cavity, on the lips (Fig. 2) and between the pharynx and oesophagus, pairs of symmetrical papillae, around teeth are observed (Fig. 3). The short oesophagus is joined to pharynx papillae.

\section{Histological description}

The first part of the digestive tract is constituted by the mouth, teeth and lips. The gill arches are taken as the dividing line between the buccalpharynx cavity and the rest of the digestive tract.

The mouth is small, round and bent, located to the right of the lateral line. The teeth are found in a group in the papillae, which are immersed in the mucosa (Fig. 4 and 5). The mucosa presents a stratified squamous epithelium and under this epithelium densely packed connective tissue fibers oriented parallel to the surface are observed. Striated muscles occur peripheral to the connective tissue where jaw muscles are present.

Scanning electron microscopy of the Solea senegalensis oesophagus showed primary longitudinal folds, on which secondary folds (Fig. 6) were also observed. The surface of the epithelial cells exhibited short apical microvilli. In the secondary folds, mucous cells were observed (Fig. 7). Histologically, the oesophagus was composed of the following layers: mucosa, submucosa, muscular and serosa (Fig. 8 and 9). The mucosa was formed by longitudinal folds, which were continuations of those of the pharynx but deeper. Transverse sections showed that minor longitudinal folds occured between the major ones, allowing expansion of the oesophagus. Taste buds were not present. The anterior oesophagus is formed predominantly of a stratified epithelium having a well defined basement membrane, with goblet cells and cubical epithelial cells within the mucosa layer (Fig. 9). The stratified epithelium layer acts as a supporting tissue surrounding and packing the goblet cells. Near the junction of the oesophagus and the stomach (oesogaster), the squamous epithelium is substituted, on the top of the oesophagus folds, by a simple columnar epithelium devoid of goblet cells (Fig. 10). Peripheral to the epithelium there is a thick layer of densely packed connective tissue fibers, the stratum compactum (Fig. 9), which separates the mucosa from submucosa (loose connective tissue). Two layers of striated muscle occur at the periphery of the connective tissue: an inner longitudinal layer, and a thicker outer circular layer. Both muscular layers are still present in the anterior part of the stomach where they are replaced by smooth muscle, and the muscular fibers invert their position. The serosa consists of mesothelial cells and loose connective tissue containing capillaries, and small blood vessels. 


\section{Ultrastructural characteristics}

Two morphological types of epithelial cells were distinguishable in the oesophageal mucosa: the more numerous type-cells had an electron-dense cytoplasm, whereas the cytoplasm was electron-clear in the other cells (Fig. 11 and 12).

The electron- dense cells contained an irregular nucleus located in the basal half part of the cells; the cytoplasm contained 10-12 mitochondria (Fig. 11),

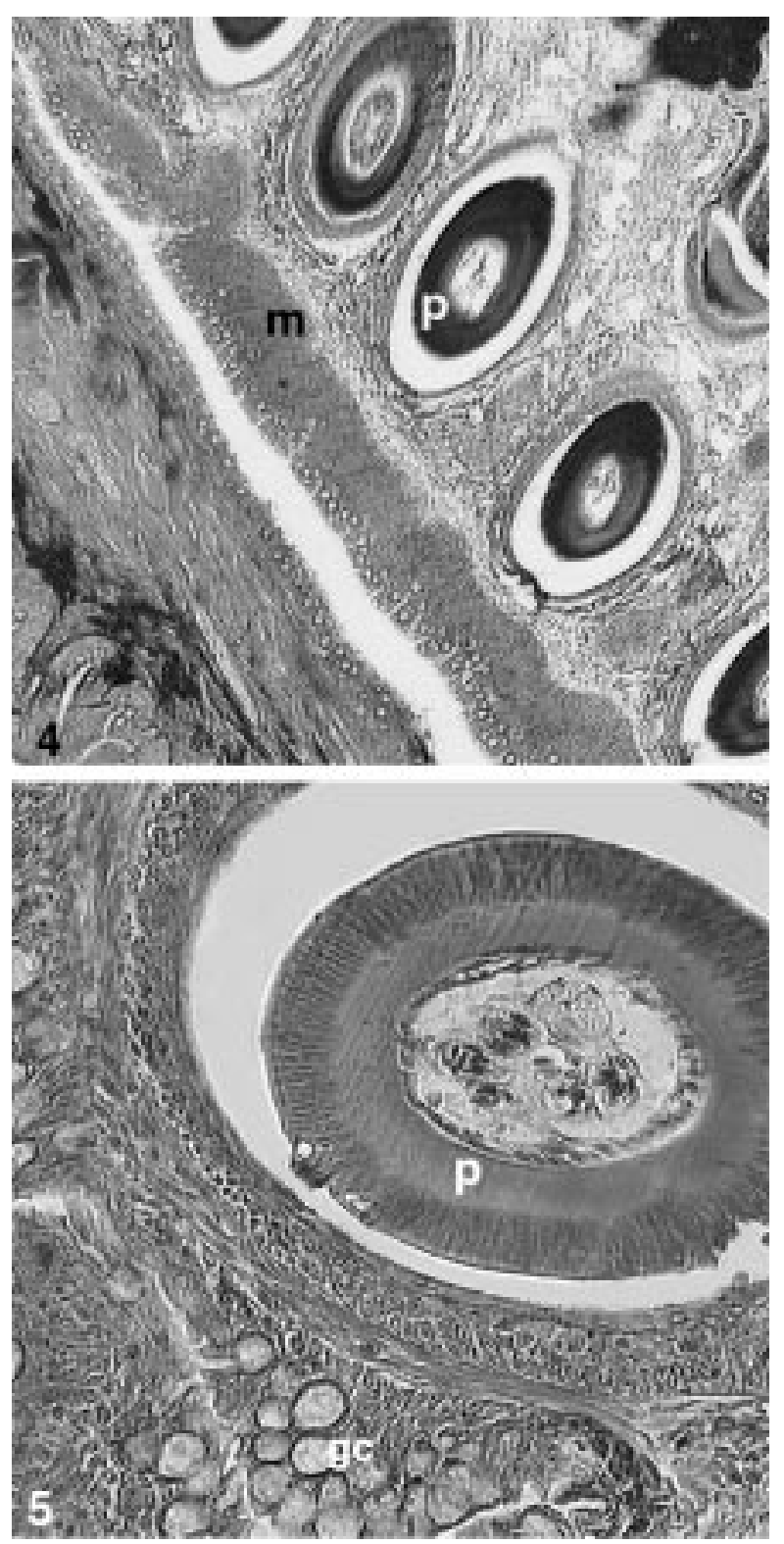

Figs. 4/5 - (4)Histological section of the papillae, showing dental formation (p) and the mucosa (m). (H/VOF x5). (5)Magnification of the dental formation (p) and the goblet cells (gc). (H/VOF x20). free ribosomes, granular endoplasmic reticulum, small spherical granules and a supranuclear Golgi apparatus consisting of several parallel cisternae, numerous vesicles and abundant tonofilaments.

Epithelial cells (electron-dense) of the outer layer exhibited short microvilli and were scarce in the glycocalyx. Neighbouring epithelial cells were intimately joined by interdigitations and many desmosomes (Fig. 13) and the intercellular spaces were dilated.

Light epithelium cells (Fig. 12) were scarce (01/each section). In the cytoplasm of these cells, 2535 mitochondria were detected (Fig. 12). The mitochondrial matrix appeared more electron-dense than the cellular hyaloplasm. The granular endoplasmic reticulum and Golgi apparatus were seldom observed. However, abundant smooth endoplasmic reticulum in tubular shape and fragmented was detected (Fig. 12).

Mucus-secreting cells are the dominant feature of the epithelium throughout the oesophagus. These goblet cells were filled with numerous mucous droplets of low electron-density (Fig. 14). The oesophagus is devoid of taste buds.

The basement membrane was quite thick. Peripheral to the basement membrane were located the fibroblasts and densely packed layers of collagen fibers of the stratum compactum. The submucosal plexus was prominent and contained myelinated (Fig. 15) and unmyelinated nerves, surrounded by Schwann cells. The musculature of the oesophagus was composed of interweaving striated muscle fibers (Fig. 16).

Near the junction of the oesophagus and the stomach (oesogaster), the squamous epithelium was substituted, on top of the oesophagus folds, by a simple columnar epithelium devoid of goblet cells (Fig. 17). In the mucosa of oesogaster, three types of cells were distinguished: dark epithelial, rodlet and light epithelial cells.

Dark epithelial cells (Fig. 17) showed different characteristics from oesophageal cells. The nucleus was irregular with an electron-dense hyaloplasm. The cytoplasm had a scarce smooth and granular endoplasmic reticulum; a Golgi apparatus consisting of four parallel cisternae, dense granules without membrane, lysosomes and numerous mitochondria (45-50/section) with an electron-dense matrix.

Rodlet cells were elongated. They contained rodlike structures and were surrounded by an electrondense capsule-like structure. The bulk of the cells was composed of up to 20 extended rodlet units 
(Fig. 18 and 19). An electron-dense core was observed in the centre of each rodlet unit (Fig. 19).

Light epithelial cells of the oesogaster had the same characteristics as those observed in the oesophagus. Numerous mitochondria with a dense matrix, abundant smooth endoplasmic reticulum and numerous vesicles were observed.

In the oesogaster, the lamina propria was more compact and distinct than in the oesophagus. Numerous fibroblasts were observed in the lamina propria of the oesogaster and the muscular portion was formed of striated muscle fibers.

\section{Histochemistry}

Buccal cavity and papillae

One type of acid mucosubstance was identified in the goblet cells of the papillae by means of histo- chemical techniques. They were recognised as sulfomucins, since they showed alcianophilia with alcian blue $\mathrm{pH} 1.0$ and 0.5 .

The reactions that made evident neutral mucopolysaccharides/glycoproteins (Fig. 20) were positive in the lamina propria and in the dental formation, although they were weakly positive in the epithelial and goblet cells (Table III). On the other hand, the dental formation showed a weak presence of carboxylated mucosubstances (Fig. 21) and glycogen.

Proteins (Fig. 22) were located in the papillae, and in particular, those rich in amino acids (Table III) such as arginine, cystine, cysteine and tryptophan were observed in the dental formation. Proteins rich in arginine were detected in the lamina propria and epithelium of the buccal cavity.

Goblet cells of the papillae (Fig. 22) were nega-
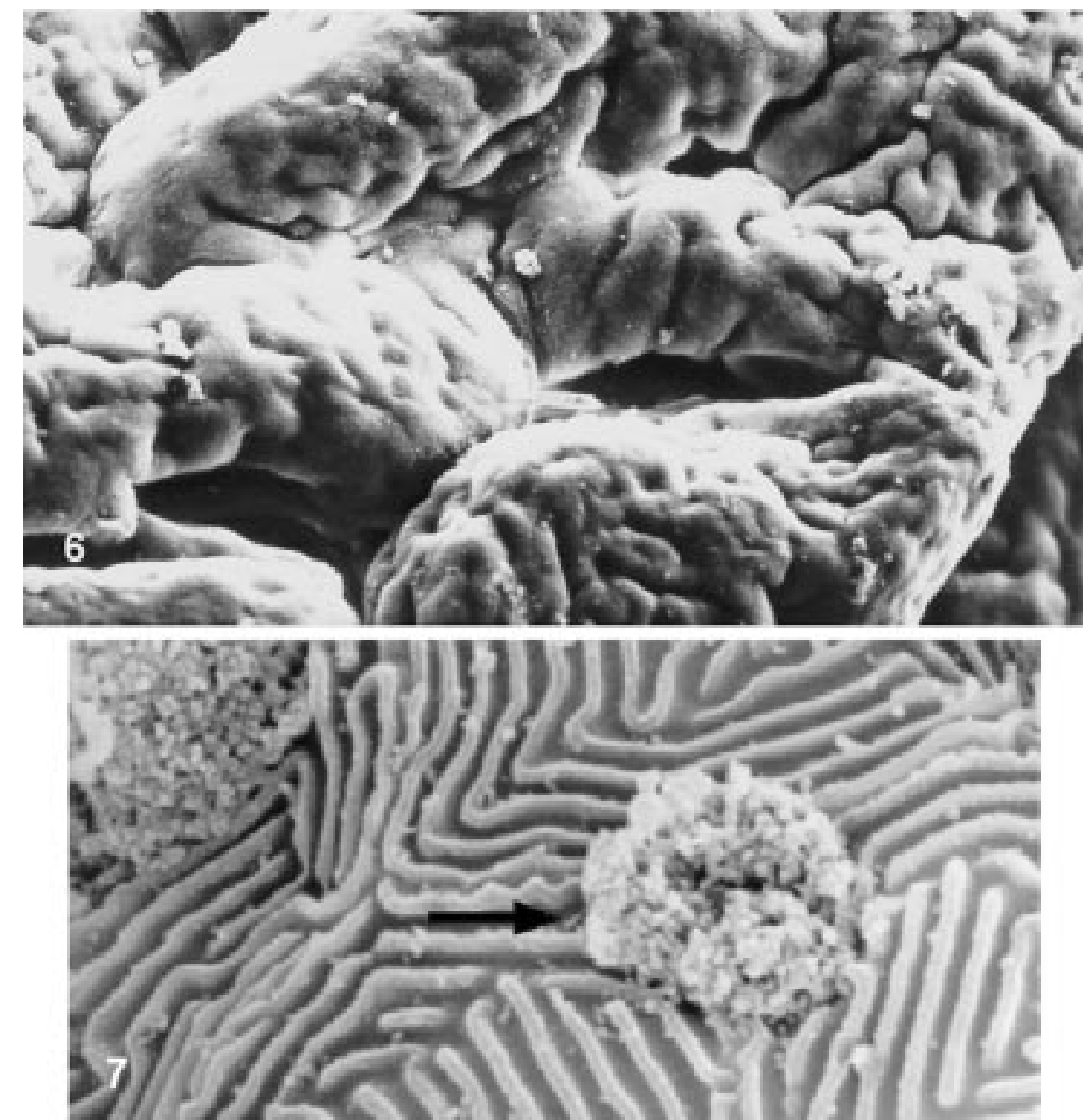

Figs. 6/7 - (6)Oesophagus secondary folds (x700). (7)Oesophagus goblet cell $(\rightarrow)$ (x1920). 
tive to the general protein technique (bromophenol blue) and contained-S-S- and -SH groups (Fig. 23, 24 and 25).

The epithelium and lamina propria of the buccal cavity contained a weak presence of acid, unsaturated and neutral lipids (Table IV). In the buccal cavity, ATPase ( $\mathrm{pH}$ 7.2) activity was detected in the epithelium and lamina propria, while ATPase (pH 9.2) and alkaline phosphatase activities presented a weak positivity (Table IV). Acid phos-

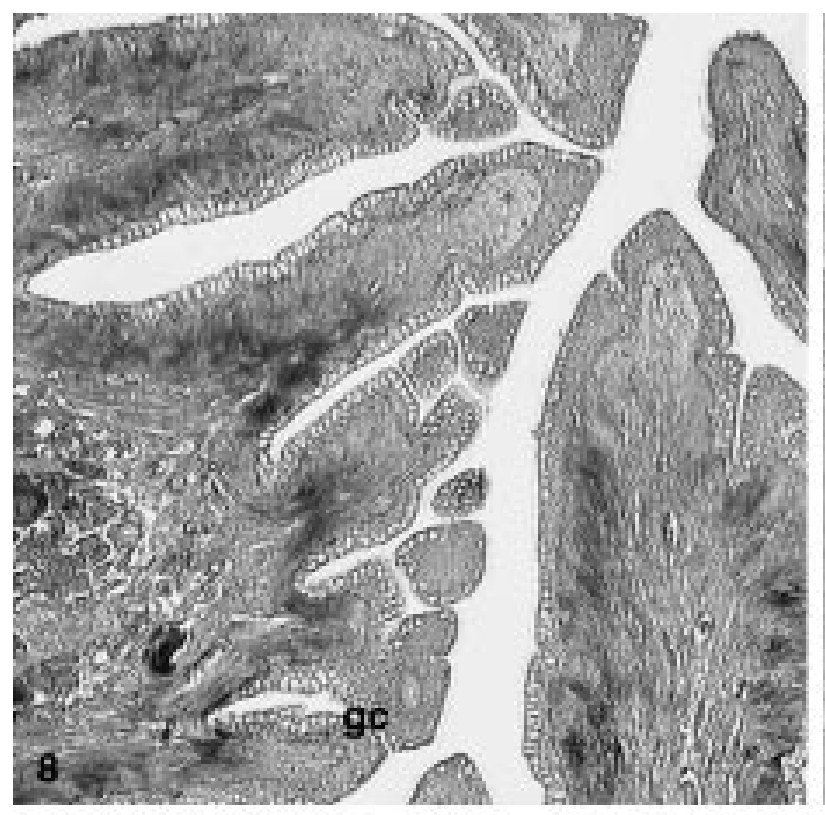

phatase activity was observed in the epithelium of the buccal cavity. Enzymatic activities and lipid reactions were negative in the goblet cells.

\section{Oesophagus}

A weak presence of acid and neutral mucopolysaccharides were observed in oesophageal epithelial cells. Goblet cells of the oesophagus (Fig. 26) were strongly stained with alcian blue $(\mathrm{AB} \mathrm{pH} 2.5)$, indicating the presence of carboxylated, sulphated

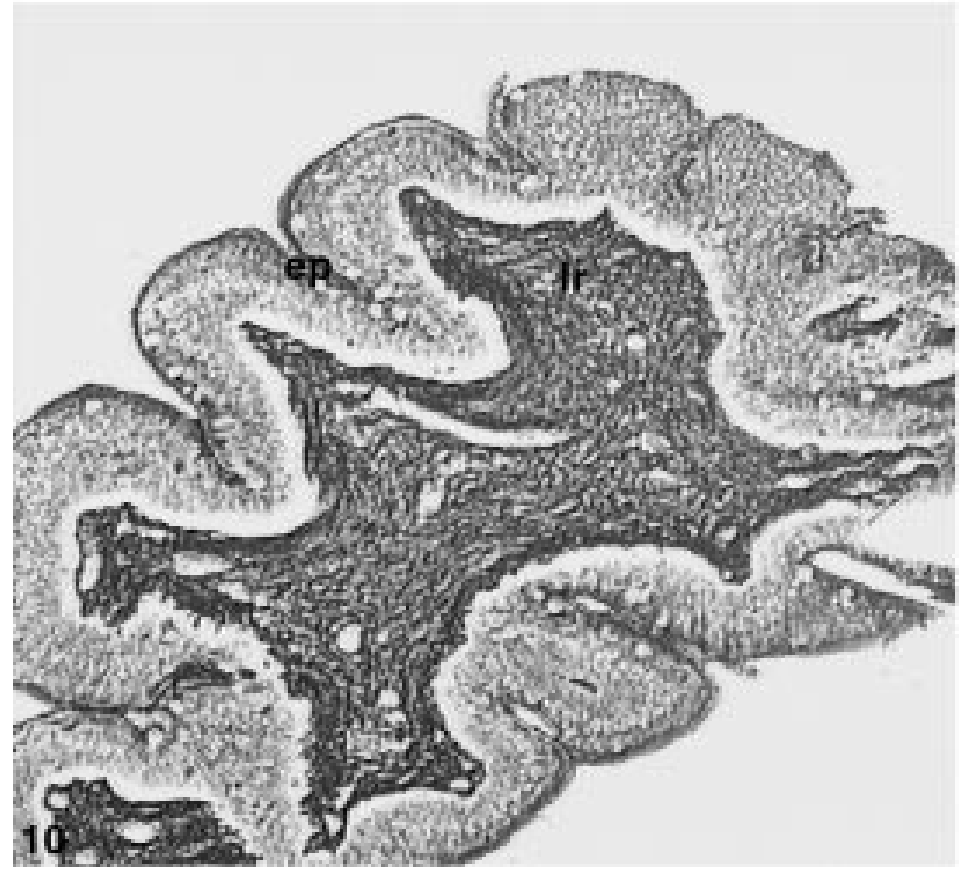

Figs. 8/10 - (8)Goblet cells (gc) in the epithelium of the anterior oesophagus (H/VOF x5). (9)Transverse section of the anterior oesophagus, showing the goblet cells $(\mathrm{gc})$ in the mucosa (m), the "stratum compactum" (sc) in the submucosa and the muscular (mu) (H/VOF x5). (10)Epithelium (ep) and the lamina propria (lr) in the posterior oesophagus. (Argentic Impregnation x10). 
(weakly and strongly ionised) mucosubstances (AB $\mathrm{pH} 1.0,0.5)$ and sialic acid (neuraminidase or $\mathrm{HCl}$ hydrolysis-AB, pH 2.5) (Table V).

Most goblet cells lacked proteins and contained -SH and -S-S- groups (Table V). Proteins (Fig. 27), and in particular those rich in lysine, tyrosine (Fig. 28) and arginine were present in the epithelium, lamina propria, submucosa and muscular layers (Table V).

Lipids in general and phospholipids were observed in the mucosa epithelium, while unsaturated, acid and neutral lipids were not observed. Lamina propria and submucosa contained a weak presence phospholipids and unsaturated lipids (Table VI).

Goblet cells of the oesophagus and the buccal cavity were negative to lipid and enzymatic reactions. Acid phosphatase (Fig. 29) and ATPase (pH 7.2) activities were observed in the lamina propria, submucosa and muscular portion of oesophagus, while ATP-ase (pH 9.2) activity was weak in these areas. ATPase (pH 7.2 and 9.5) were feeble in the epithelium (Table VI).

\section{DISCUSSION}

The structure of the oesophageal wall of the Senegal sole, Solea senegalensis is similar to other teleostean fish (Grau et al., 1992; Gargiulo et al., 1996) and consists of four layers: mucosa, submucosa, muscular and serosa. The lining epithelium is stratified and the muscularis consist of striated muscled fibers, as in Sparus aurata, Seriola dumerili and Tilapia sp (Elbal and Agulleiro, 1986a; Grau et al., 1992; Gargiulo et al., 1996).

Fingerprint-like microridges on the squamous epithelial cells of the gut mucosa of the Senegal sole have been described in other species (Meister et al., 1983; Morrison, 1987; Grau et al., 1992) and these microridges may protect the surface from trauma from ingested materials and anchor the mucus secreted by goblet cells (Ezeasor and Stokoe, 1980; Humbert et al., 1984; Uehara and Miyoshi, 1988). In the Senegal sole, the lamina propria was practically indistinguishable, and the stratum compactum, which separated the mucosa from the loose connective tissue -the submucosa- was well developed, such as Grau et al. (1992) observed in Seriola dumerili. On the other hand, S. Senegalensis presented powerful layers of striated muscle in the oesophageal surface that according to Grau et al. (1992) might act as the main grinding device.

A notable characteristic of the oesophagus of the
Senegal sole is the absence of taste buds, as occurs in seabream and tilapine (Elbal and Agulleiro, 1986a; Gargiulo et al., 1996). However, taste buds have been observed in different fish species (Reifel and Travill, 1977; Martin and Blaber, 1984).

In the oesophagus of the Senegal sole, two different morphological types of epithelial cells were distinguishable: the more numerous cells had electrondense cytoplasm, whereas the cytoplasm was electron-clear in the other cells. Light epithelial cells contained numerous mitochondria. Similar epithelial cells present in the oesophagus of S. Senegalensis have been described in Salmo gairdneri (Weinreb and Bisbal, 1955) and in Sparus aurata (Elbal and Agulleiro, 1986a), although the authors did not notice any ultrastructural differentiation between clear and dense epithelial cells. The electron-dense cells in S. senegalensis were not excessively mitochondria-rich but the intercellular spaces were dilated. Meister et al., (1983) observed similar cell types in mid and posterior oesophagus of sea-water fish species. According to different authors (Kirsh, 1978; Berridge and Oschman, 1972; Yamamoto and Hirano, 1978; Meister et al., 1983), the association of mitochondria and dilated intercellular spaces with the absence of significant transepithelial net water fluxes (Kirsch, 1978) is generally related to an active ion transport on lateral membranes and rapid "entrainment" of solutes in intercellular spaces with baso-lateral water recycling (Yamamoto and Hirano, 1978). Similar intercellular spaces as observed in the Senegal sole have been described in the columnar epithelium of the Anguilla japonica oesophagus during sea water adaptation, being characterised by a selective ion permeability independent of that of water (Yamamoto, 1978). The electron-clear epithelial cells were observed in the oesophagus and oesogaster of S. Senegalensis. These cells, rich in mitochondria, showed elements of a tubular system similar to those described by Pisam (1981) for chloride cells of teleost gills; and according to Arellano (1999) these cells were also stained with osmium tetraoxide by using the technique of Watrin and Mayer-Gostan (1996), a widely used technique which does not employ antibodies. This substantiates the hypothesis that these clear dense epithelial cells are ion-transporting cells. According to Meister et al., (1983), dilated intercellular spaces were not necessarily related to ion absorption.

In the oesogaster of $S$. Senegalensis, rodlet cells were observed throughout the digestive tract (Arel- 

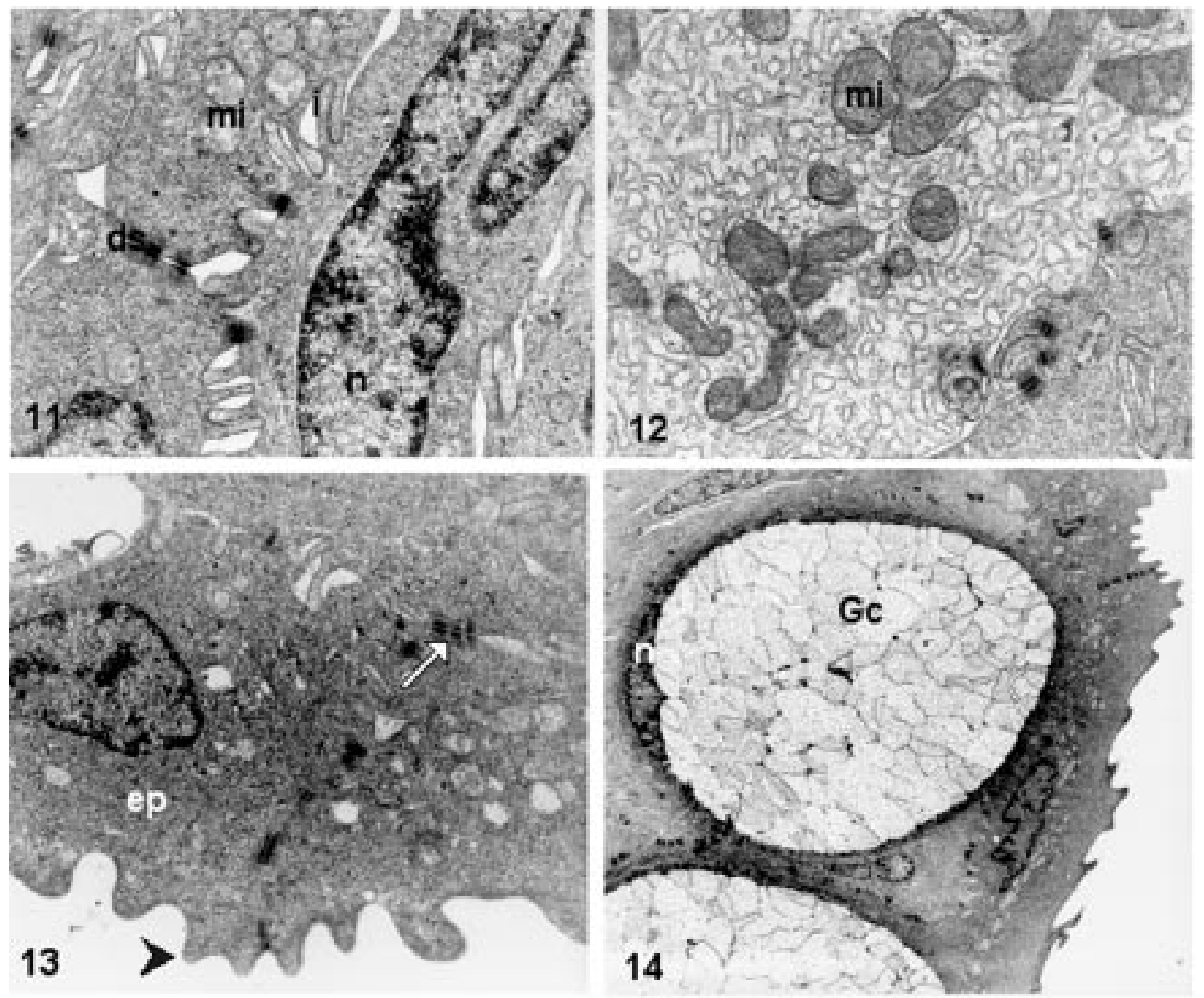

14
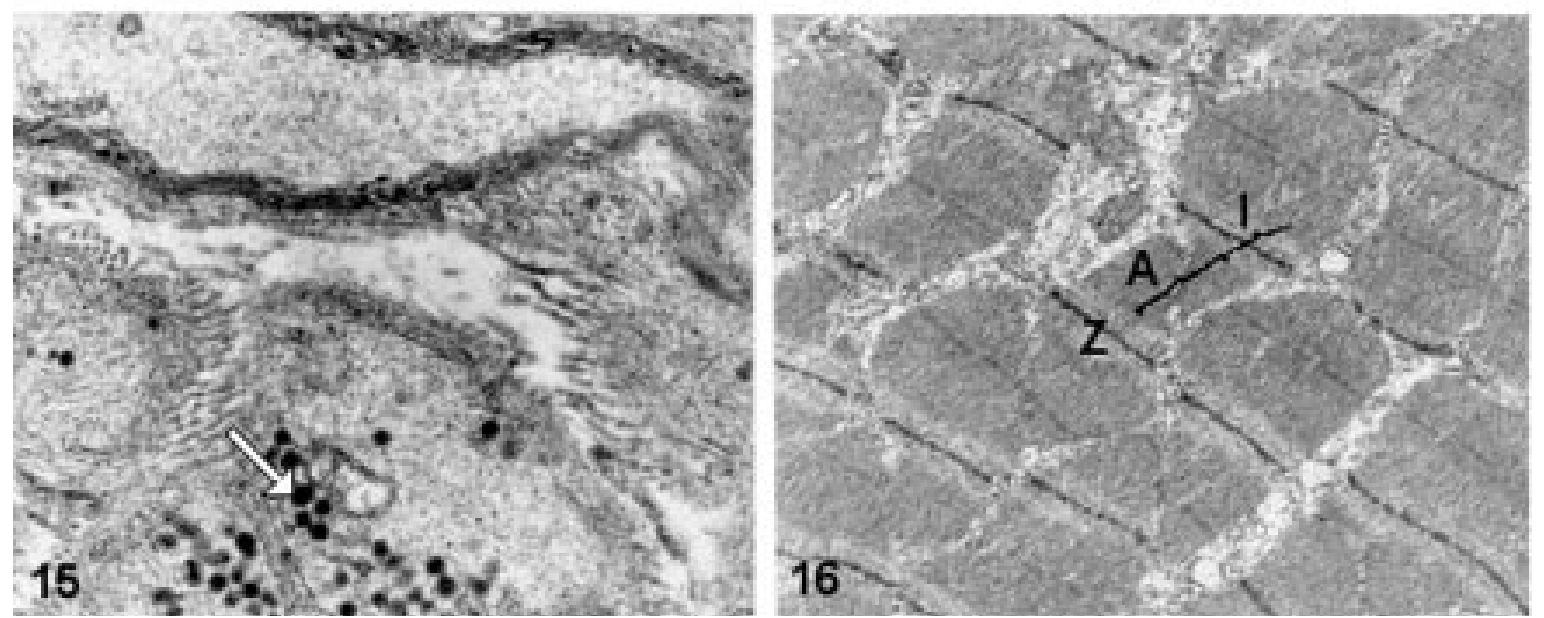

Fig. 11/16 - (11)Oesophageal epithelium showing the dark cells with cytoplasm electron-dense and a plasmalema with numerous interdigitations (i) and desmosomes (ds). The nucleus (n) is long and irregular, and in the cytoplasm are observed numerous mitochondrias (mi) (x20000). (12)Light epithelial cells showing numerous mitochondria (mi) and abundant smooth endoplasmic reticulum in tubular shape and fragmented (x25000). (13)Epithelial cells (ep) in the oesophagus apical showing microvilli and desmosomes (x16000). (14)Goblet cell ( $\mathrm{gc}$ ) detected in the nucleus $(\mathrm{n})(\mathrm{x} 4000)$. (15)The submucosal plexus, showing myelinated nerves $(\rightarrow)$ (x25000). (16)The musculature of the oesophagus is composed of interweaving striated muscle fibers (x10000). 
Table III

Histochemical distribution of carbohydrates and proteins in the papillae of S. senegalensis

\begin{tabular}{lllll}
\hline & Epithelium & Goblet cells & Lamina propria & Teeth \\
\hline Glycogen & 0 & 0 & 0 & $0-1$ \\
Neutral glycoproteins & $0-1$ & $0-1$ & $2-3$ & 3 \\
Carboxylated groups & 0 & $2-3$ & 0 & $0-1$ \\
Sulphated glycoconjugates (weakly ionised) & 0 & 3 & 0 & 0 \\
Sulphated glycoconjugates (strongly ionised) & 0 & $2-3$ & 0 & 0 \\
Hydrochloric acid hydrolysis AB pH 2.5 & 0 & 0 & 0 & 0 \\
Esterification-AB pH 2.5 & 0 & 0 & 0 & 0 \\
Esterification -Saponification-AB pH 2.5 & 0 & $2-3$ & 0 & $0-1$ \\
Esterification-AB pH 1.0 & 0 & 0 & 0 & 0 \\
Esterification -Saponification-AB pH 1.0 & 0 & 0 & 0 & 0 \\
Esterification-AB pH 0.5 & 0 & 0 & 0 & 0 \\
Esterification -Saponification-AB pH 0.5 & 0 & 0 & & 3 \\
& & 0 & $2-3$ & 3 \\
Proteins in general & 2 & $0-1$ & $0-1$ \\
Proteins rich in lysine & $0-1$ & 0 & $0-1$ & 2 \\
Proteins rich in tyrosine & $0-1$ & 0 & 2 & $2-3$ \\
Proteins rich in arginine & 1 & 0 & $2-1$ & 2 \\
Proteins rich in tryptophan & $2-1$ & 0 & 2 & 2 \\
Proteins with cysteine residues & 2 & $2-3$ & 2 & 0 \\
Proteins with cystine residues & 2 & 3 & 0 \\
\hline
\end{tabular}

Results are expressed as semiquantitative assessment of colour intensities by independent scores of two investigators. Estimated scale ranging from 0 (unreactive) to 3 (strongly reactive).

lano, 1999). These cells are present in the epithelium of numerous organs/tissues (gills, digestive tract, heart, thymus, skin, etc.) of both freshwater and marine teleostean fish (Leino, 1981; Iger and Abraham, 1997; Dezfuli et al., 1998). Although the nature of these cells remains controversial, studies on their fine structure have supported the view that rodlet cells are secretory/enzymatic cells (Leino, 1981). These cells could be found under conditions of experimental wounding and after exposure to lead (or cadmium) polluted water, diluted seawater, manured water, acidified water, after thermal elevation or after exposure to polluted water (Iger and Abraham, 1997).

An integral component of the digestive mucous layer are the mucins, which in conjunction with locally secreted components are crucial for the functioning of epithelial cells. Mucins are high molecular weight glycoproteins forming intricate networks. They protect the mucous membranes of the gastrointestinal system, and other bodily portions (skin, gills) by forming a viscoelastic gel which acts as a physical barrier between the mucosa and environmental agents (Pajak and Danguy, 1993). Sulfo- mucins, sialomucins and neutral mucosubstances/glycoproteins were observed in mucous

Table IV

Histochemical distribution of lipids and enzymatic activities in buccal cavity of $S$. senegalensis

\begin{tabular}{lccc}
\hline & Epithelium & $\begin{array}{c}\text { Goblet } \\
\text { cells }\end{array}$ & $\begin{array}{c}\text { Lamina } \\
\text { Propria }\end{array}$ \\
\hline $\begin{array}{l}\text { Unsaturated lipids } \\
\text { Neutral lipids }\end{array}$ & 1 & 0 & $0-1$ \\
$\begin{array}{l}\text { Acid lipids } \\
\text { Phospholipids }\end{array}$ & 1 & 0 & $0-1$ \\
& 0 & 0 & $0-1$ \\
Alkaline phosphatase & $0-1$ & 0 & 0 \\
$\begin{array}{l}\text { Acid phosphatase } \\
\text { ATPase (pH 7.2) }\end{array}$ & $1-2$ & 0 & $0-1$ \\
ATPase (pH 9.4) & $2-3$ & 0 & 3 \\
& $0-1$ & 0 & $0-1$
\end{tabular}

Results are expressed as semiquantitative assessment of colour intensities by independent scores of two investigators. Estimated scale ranging from 0 (unreactive) to 3 (strongly reactive). 

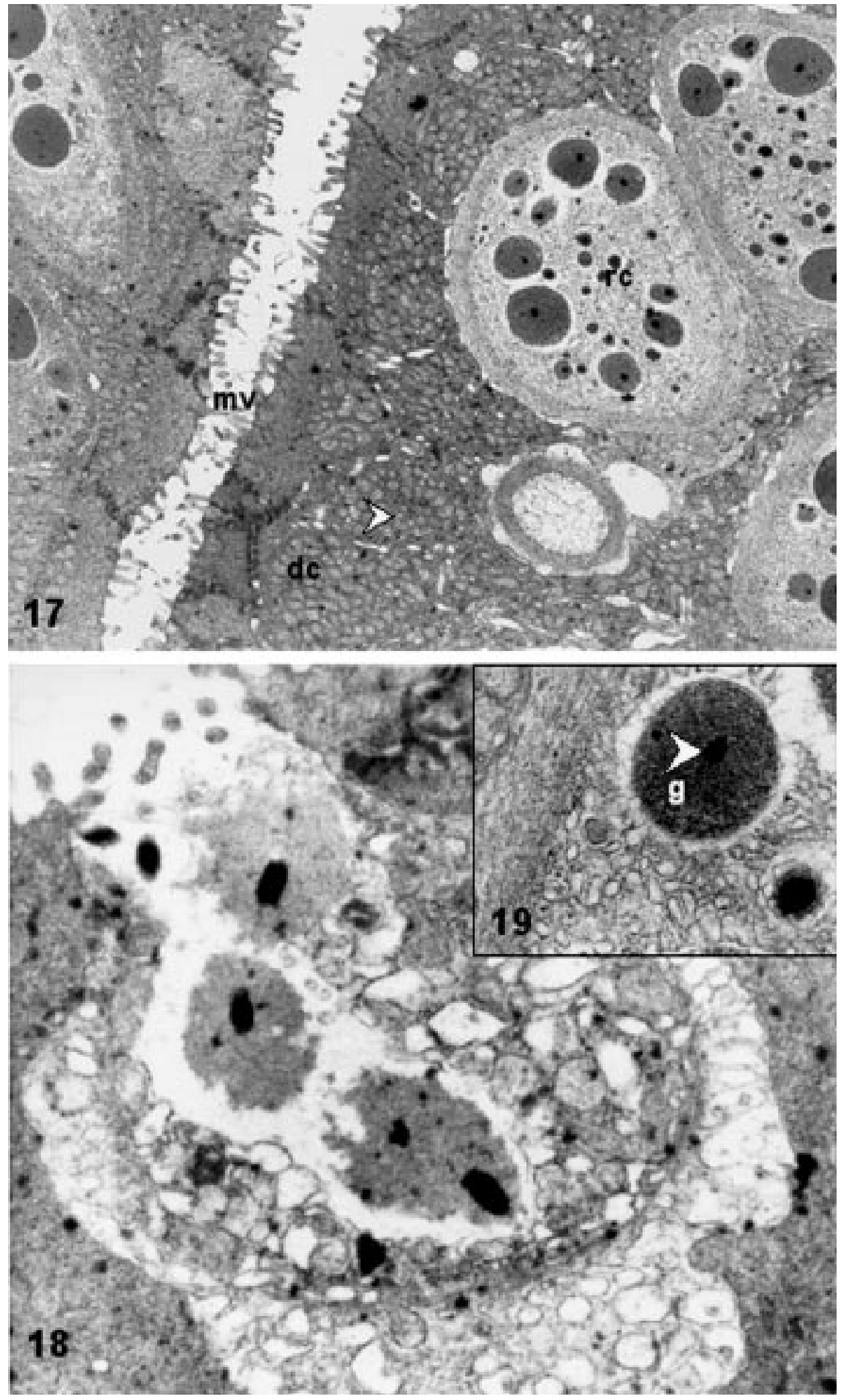

Figs. 17/19 - (17)Oesogaster epithelium, showing numerous rodlet cells (rc), dark cells (dc) (numerous mitochondrias $(\triangleright)$ and the microvilli (mv) (x5800). (18)Rodlet cell spilling its contents (x26600). (19)Magnification of the rodlet cell showing the dense granules $(\mathrm{g})$ and droplet in the middle ( $\triangleright$ ) (x2400). 

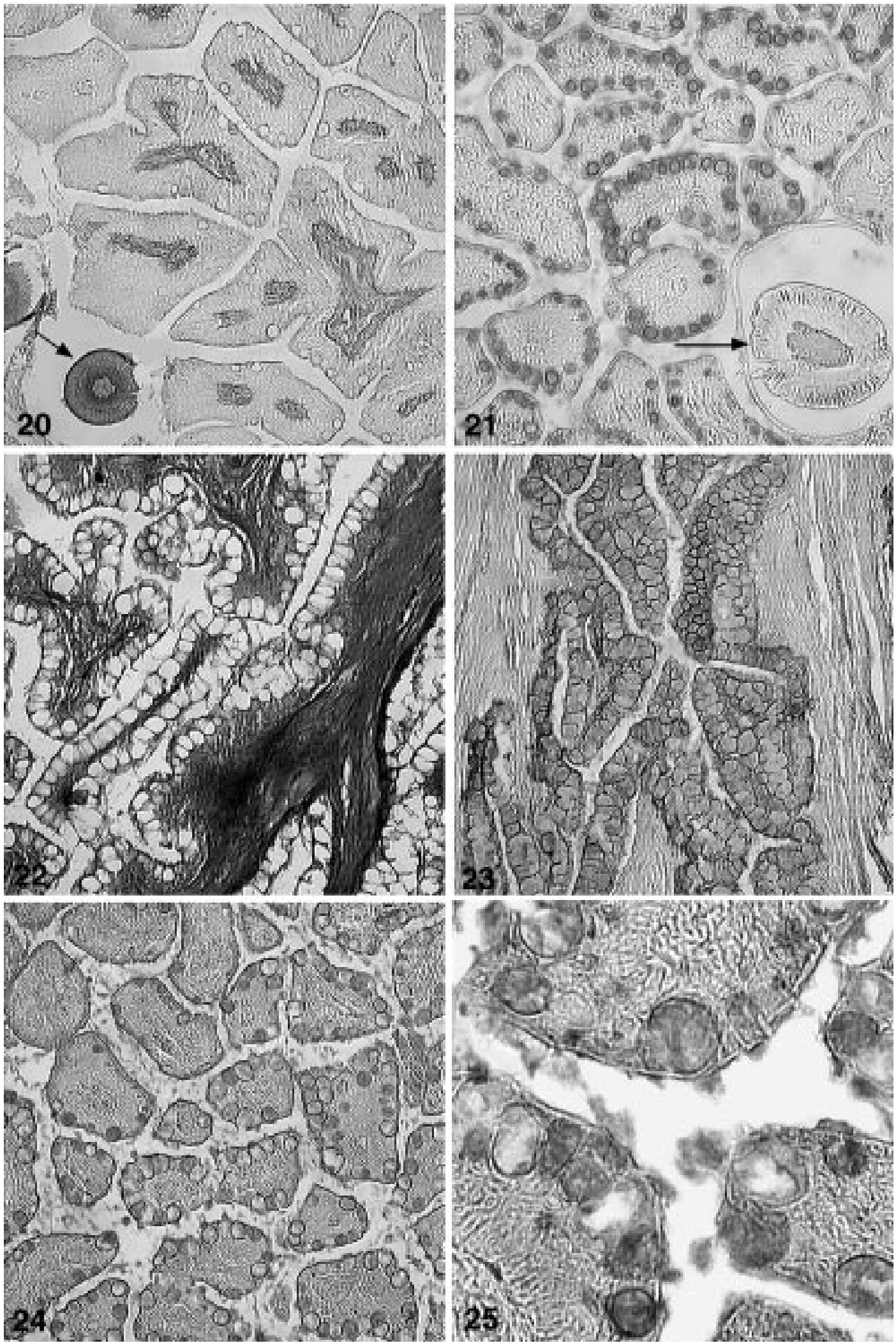
Table V

Histochemical distribution of carbohydrates and proteins in oesophagus of S. senegalensis

\begin{tabular}{lccccc}
\hline & Epithelium & Goblet cells & Lamina Propria & Submucosa & Muscular \\
\hline Glycogen & 0 & 0 & 0 & 0 & 0 \\
Neutral glycoproteins & $0-1$ & $0-1$ & 2 & $1-2$ & 1 \\
Carboxylated groups & $0-1$ & 3 & 0 & 0 & 0 \\
Sulphated glycoconjugates (weakly ionised) & $0-1$ & $2-3$ & 0 & 0 & 0 \\
Sulphated glycoconjugates (strongly ionised) & 0 & 2 & 0 & 0 & 0 \\
Hydrochloric acid hydrolysis AB pH 2.5 & 0 & $0-1$ & 0 & 0 & 0 \\
Esterification-AB pH 2.5 & 0 & 0 & 0 & 0 & 0 \\
Esterification -Saponification-AB pH 2.5 & $0-1$ & 3 & 0 & 0 & 0 \\
Esterification-AB pH 1.0 & 0 & 0 & 0 & 0 & 0 \\
Esterification -Saponification-AB pH 1.0 & 0 & 0 & 0 & 0 & 0 \\
Esterification-AB pH 0.5 & 0 & 0 & 0 & 0 & 0 \\
Esterification -Saponification-AB pH 0.5 & 0 & 0 & 0 & 0 & 0 \\
& & & $2-3$ & $2-3$ & $2-3$ \\
Proteins in general & 2 & $0-1$ & 2 & $1-2$ & 2 \\
Proteins rich in lysine & 2 & 1 & 1 & 1 & 2 \\
Proteins rich in tyrosine & 2 & 0 & 2 & $2-3$ & 3 \\
Proteins rich in arginine & 1 & 0 & 0 & 0 & 0 \\
Proteins rich in tryptophan & 0 & 0 & $2-3$ & $2-3$ & $2-3$ \\
Proteins with cysteine residues & 3 & $2-3$ & 2 & 2 & $2-3$ \\
Proteins with cystine residues & 2 & 2 & 0 & 0 \\
\hline
\end{tabular}

Results are expressed as semiquantitative assessment of colour intensities by independent scores of two investigators. Estimated scale ranging from 0 (unreactive) to 3 (strongly reactive).

cells of the oesophagus of $S$. senegalensis, as in Mugil saliens (Elbal and Agulleiro, 1986b); mucous secretion could protect from the abrasion that nutritive particles produce (Elbal and Agulleiro, 1986b). Glycoproteins containing sialic acid were also observed in the oesophageal mucous cells of S. senegalensis. Reifel and Travill (1977) postulated that the large amount of mucus secreted does not seem to be explicable simply as a lubricant. It is important to note that salivary glands are lacking in most fish species so the oesophageal mucous cells could have the same function as mammalian saliva in protecting the mucosa of the entire alimentary canal. This notion was also expressed by Scocco et al. (1998) regarding the tilapine oesophagus althought here the sialoglycoconjugates displayed an organisation which was unusual in mammals (Klein et al., 1992; Wu et al., 1994). As Zimmer et al. (1992) reported, the presence of sialic acid residues in mucous cells prevents viruses from recognising their receptor determinants and also protects the mucosa from attack by sialidase produced by bacteria.

Neutral and acid mucins were also detected in intestinal goblet cells of Solea solea larvae (Boulhic and Gabaudan, 1992), and sialosulphoglycoproteins and neutral glycoconjugates were observed during larval development of Sparus aurata (Sarasquete et al., 1995; Domeneghini et al., 1998). Weakly ionised sulphomucins were detected in intestinal goblet cells of adult (Arellano et al., 1999), larvae and juvenile Solea senegalensis specimens (Ribeiro et al., 1999; Vieira, 2000).

The weak presence of neutral mucosubstances and acid mucins in the oesophagus of $S$. senegalensis was also observed in Seriola dumerili (Grau et al., 1992). According to Kapoor et al. (1975), the oesophagus of fish species has a secretory rather than an absorptive function.

The protein content of the different portions of the digestive tract of teleost has rarely been investigated using histochemical tests. Goblet cells of the Sene-

Figs. 20/25 - (20)Dental formation $(\rightarrow$ ). PAS (x10). (21)Dental formation $(\rightarrow$ ). Alcian blue pH 2.5 (x10). (22)Papillae mucosa. Bromophenol blue (x10). (23)Papillae mucosa. Cysteine (x10). (24)Papillae mucosa. Cystine (x10). (25)Magnification of goblet cells. Cystine (x40). 

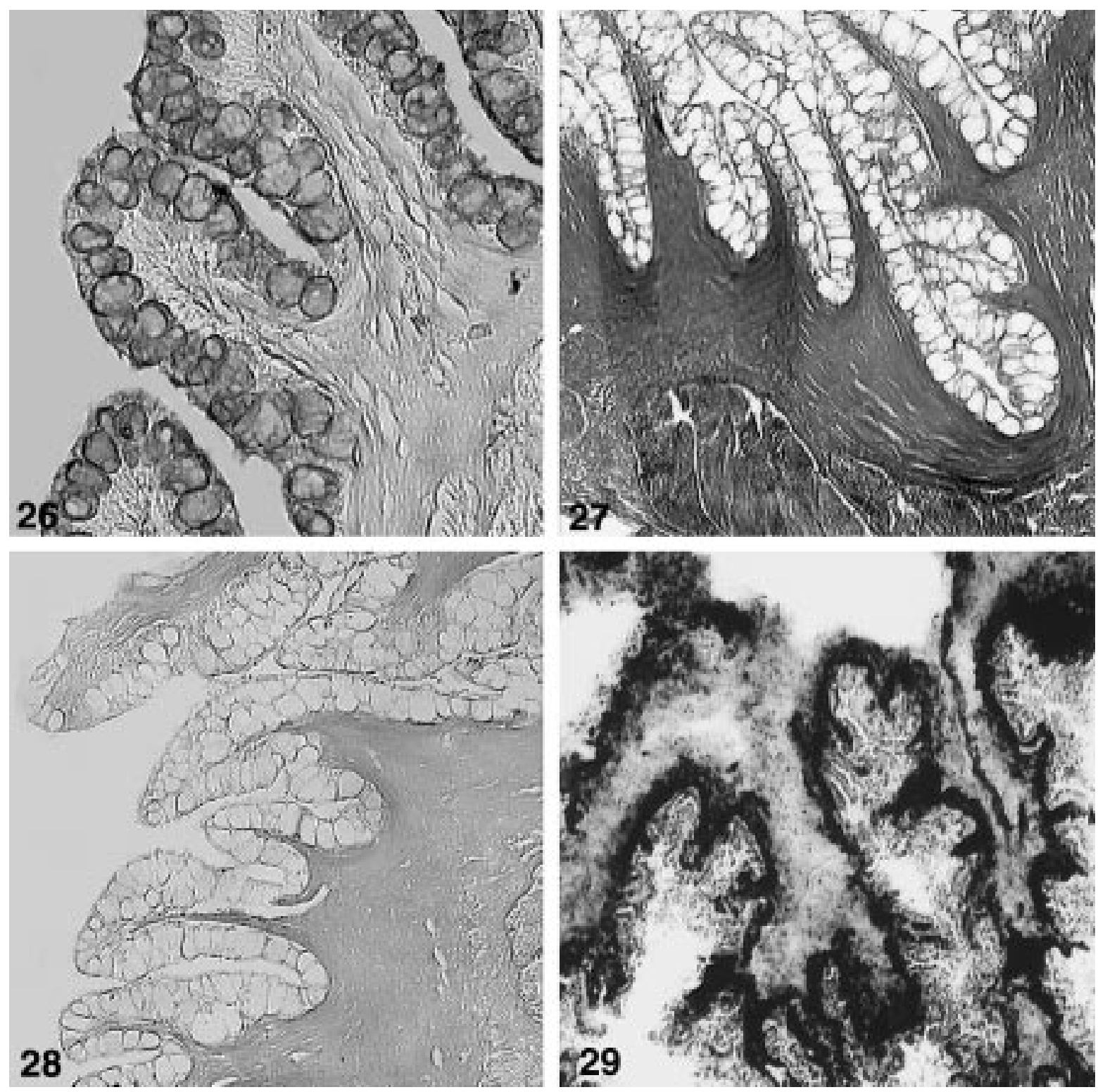

Figs. 26/29 - (26)Oesophageal mucosa. Alcian blue pH 2.5/PAS (x20). (27)Oesophageal mucosa and mucular. Bromophenol Blue (x10). (28)Oesophageal mucosa. Tyrosine (x10). (29)Oesophageal mucosa. Acid phosphatase activity (x5).

gal sole oesophagus contained $-\mathrm{S}-\mathrm{S}$ and $-\mathrm{SH}$ groups; proteins rich in lysine, tyrosine, arginine, cystine and cysteine were observed in the epithelial cells, lamina propria, submucosa and muscularis. Similar results were observed in Sparus aurata oesophagus (Arellano, 1995).

As in other fish species (Arellano, 1995; Grau et al., 1992; Sarasquete et al., 1995; Ribeiro et al., 1999), the mucous cells of the oesophageal and buccal cavity of S. senegalensis were negative for the lipid reactions and enzymatic activities.

\section{ACKNOWLEDGEMENTS}

The authors are grateful to Mrs. Mummert, Mrs. Adams, Mrs. Kempendorf and Mrs. Viaña for technical assistance. Special thanks to Dr. M. Teresa Dinis. This work was supported by Interreg II Project EC (19/REGII/6/96; Portugal-Spain), and by a grant to J.M.A. (AquaTT \& Sata. Leonardo Programme EC). 
Table VI

Histochemical distribution of lipids and enzymatic activities in oesophagus of S. senegalensis

\begin{tabular}{lccccc}
\hline & Epithelium & Goblet cells & Propria Lamina & Submucosa & Muscular \\
\hline Unsaturated lipids & 0 & 0 & 1 & 1 & 1 \\
Neutral lipids & 0 & 0 & 0 & 0 & 0 \\
Acid lipids & $0-1$ & 0 & 0 & 0 & $0-1$ \\
Phospholipids & 1 & 0 & 1 & 1 & 0 \\
Alkaline phosphatase & 0 & 0 & 0 & 0 & 0 \\
Acid phosphatase & 1 & 0 & 2 & 2 & $2-3$ \\
ATPase (pH 7.2) & 1 & 0 & 2 & 2 & 2 \\
ATPase (pH 9.4) & 1 & 0 & 1 & 1 & 1 \\
\hline
\end{tabular}

Results are expressed as semiquantitative assessment of colour intensities by independent scores of two investigators. Estimated scale ranging from 0 (unreactive) to 3 (strongly reactive).

\section{REFERENCES}

Amin A.B., Mortensen L., and Poppe T.T.: Histology atlas, normal structure of salmonids. International edition $\left(2^{\mathrm{a}}\right)$. Norway, pp. 234, 1994.

Arellano J.M.: Contribución a la histología, histoquímica e histopatología de la dorada, Sparus aurata, L. Tesis de Licenciatura. Univ. Cádiz, pp. 116, 1995.

Arellano J.M.: Descripción morfoestructural e histoquímica del lenguado senegalés, Solea senegalensis. Cuantificación y efectos hitopatológicos del cobre. Tesis Doctoral. Univ. Cádiz, Spain, pp. 357, 1999

Arellano J.M., Dinis M.T., and Sarasquete C.: Histomorphological and histochemical characteristics of the intestine of Senegal sole, Solea senegalensis. Eur. J. Histochem. 43, 121-133, 1999.

Bancroft J.D., and Stevens A.: Theory and practice of histological techniques. $2^{\text {nd }}$ edition. Churchill Livingstone, Edinburg, London, 1990.

Barrington E.J.W.: The alimentary canal and digestion. In The Physiology of Fishes (Brown, M.E., ed.), New York, London: Academic Press. Vol I, pp. 109-161, 1957.

Berridge M.J., and Oschman J.L.: Solute-solvent interactions in epithelia: In: Locke M (ed) Transporting epithelia. Academic Press, New York, pp. 5-8, 1972.

Boulhic M., and Gabaudan J.: Histological study of the organogenesis of the digestive system and swim bladder of the Dover sole, Solea solea (Linnaeus, 1758). Aquaculture. 102, 373-396, 1992.

Cataldi E., Crosetti D., Conte G., D'Ovidio D., and Cataudella S.: Morphological changes in the oesophageal epithelium during adaptation to salinities in Oreochromis mossambicus, O. Niloticus and their hybrid. J. Fish Biol. 32, 191-196, 1988a.

Cataldi E., Crosetti D., Leoni D., and Cataudella S.: Oesophagus structure during adaptation to salinity in Oreochromis niloticus (Perciformes, Pisces) juveniles. Bull. Zool. 55, 5962, 1988b.
Ciccotti E., Macchi E., Rossi A.., and Cautella S.: Glass eel (Anguilla anguilla) acclimation to freshwater and seawater: morphological changes of the digestive tract. J. Appl. Ichthyol. 9, 74-81, 1993

Dezfuli B.S., Capuano S., and Manera M.: A description of rodltet cells from the alimentary canal of Anguilla anguilla and their relationship with parasitic helminths. J. Fish. Biol. 53, 1084-1095, 1998

Domeneghini C., Pannelli Straini R., and Veggetti A.: Gut glyconjugates in Sparus aurata L. (Pisces, Teleostei). A comparative histochemical study in larval and adult ages. Histol Histopathol. 13, 359-372, 1998

Elbal M.T., and Agulleiro B.: A histochemical and ultastructural study of the gut of Sparus auratus (Teleostei). J. Submicrosc. Cytol. 18, 2, 335-347, 1986a.

Elbal M.T., and Agulleiro B. A histochemical and ultrastructural study of the gut Mugil saliens (teleost) Acta Microscópica. $9,1,31-40,1986 \mathrm{~b}$

Ezeasor D.N., and Stokoe W.M.: Scanning electron microscopic study of the gut mucosa of the rainbow trout Salmo gairdneri Richardson. J. Fish Biol. 17, 529-539, 1980.

Ferguson H.W.: Systemic pathology of fish. A text and Atlas of Comparative Tissue Responses in Diseases of Teleosts. Ames: Iowa State University Press, 1995.

Gargiulo A.M., Ceccarelli P., Dall'aglio C., and Pedini V.: Ultrastructural study on the stomach of Tilapia spp (Teleostei). Anat. Histol. Embriol. 26, 331-336, 1996.

Grau A., Crespo S., Sarasquete M.C., and González de Canales M.L.: The digestive tract of the amberjack Seriola dumerili, Risso: A light and scanning electron microscope study. J. Fish Biol. 41, 287-303, 1992.

Gutiérrez M.: Coloración histológica para ovarios de peces, crustáceos y moluscos. Inv. Pêsq. 31, 265-271, 1967.

Hirano T., and Mayer-Gostan N.: Eel oesophagus as an osmoregulatory organ. Proc. Natl. Acad. Sci. USA 73, 1348 1350, 1976 . 
Humbert W., Kirsh R., and Meister M.F.: Scanning electron microscopic study of the oesophageal mucous layer in the eel, Anguilla anguilla L. J. Fish Biol. 25, 117-122, 1984.

Iger Y., and Abraham M.: Rodlet in the epidermis of fish exposed to stressor. Tiss. Cell 29, 431-438, 1997.

Kapoor B.J., Smith H., and Verighina I.A.:. The alimentary canal and digestion in teleost. Adv. Mar. Biol. 13, 109-139, 1975.

Karnaky K.J., and Kinter W.B.: Killifish opercular skin: a flat epithelium with a high density of chloride cells. J. Exp. Zool. 199, 355-364, 1977.

Khana S.S., and Mehrotra B.K.: Morphology and histology of the teleostean intestine. Anatomische Anzeiger 129, 1-18, 1971.

Kirsh R.: Role of the oesophagus in osmoregulation in teleost fishes. In: Alfred Benzon Symposium XI. Osmotic and Volume Regulation. Copenhagen, Munksgaard, 1978.

Kirsch R., and Laurent P.: L'oesophage, organe effecteur de l'osmorégulation chez un téléostéen euryhalin, l'anguille (Anguilla anguilla L.). C.R. Acad. Sci. Paris 280, 2013-2015, 1975.

Leino R.L.: Rodlet cells in the gill and intestine of Catostomus commersis and Perca flavescens: a comparison of their light and electron microscopy cytochemistry with that of mucous and granular cells. Can. J. Zool. 60, 2728-2782, 1981.

Mancera J.M., Pérez-Figares J.M., and Fernández-Llebrez P.: Osmoregulatory responses to abrupt salinity changes in the euryhaline gilthead sea bream (Sparus aurata L.). Comp. Biochem. Physiol. 106A, 245-250, 1993.

Martoja R., and Martoja-Pierson M.: Técnicas de Histología Animal. Toray Masson. Barcelona. pp. 350, 1970.

Morrison C.M.: Histology of the Atlantic cod, Gadus morhua: an atlas. Part one. Digestive tract and associated organs. Can. Spec. Publ .Fish Aquat. Sci. 98, 1-219, 1987.

Meister M.F., Humbert W., Kirsch R., and Vivien-Roels B.: Structure and ultrastructure of the oesophagus in sea-water and fresh-water Teleosts (Pisces). Zoomorphol. 102, 33-51, 1983.

Pisam M.: Membranous systems in the "chloride cell" of teleostean fish gill; their modifications in response to the salinity of the environment. Anat. Rec. 200, 401-414, 1981.

Pajak B., and Danguy A.: Characterization of sugar moieties and oligosaccharide sequences in the digital intestinal epithelium of the rainbow trout by means of lectin histochemistry. J. Fish Biol. 43, 709-722, 1993.

Pearse A.G.E.: Histochemistry. Theoretical and Applied. $4^{\text {th }}$ edition. Churchill, Livingstone, Edinburgh. pp. 1055, 1985.

Reifel C.W., and Travill A.A.: Structure and carbohydrate histochemistry of the oesophagus in ten teleostean species. J. Morphol. 152, 303-314, 1977.

Ribeiro L., Sarasquete C., and Dinis M.T.: Histological and histochemical development of the digestive system of Solea senegalensis (Kaup, 1858) larvae. Aquaculture 171, 293-308, 1999.

Ruiter A.J.H., Hoogeveen Y.L., and Wendelaar Bonga S.E.: Ultrastructure of intestinal and gall-bladder epithelium in the teleost Gasteerosteus aculeatus L., as related to their osmoregulatory function. Cell Tissue Res. 240, 191-198, 1985.

Sarasquete C., Polo A., and Yúfera M.: Histology and histochemistry of the development of the digestive system of larval gilthead seabream, Sparus aurata L. Aquaculture 130, 7992, 1995

Sarasquete C., González de Canales M.L., Arellano J.M., Muñoz-Cueto J.A., Ribeiro L., and Dinis M.T.: Histochemical aspects of the yolk-sac and digestive tract of larvae of the Senegal sole, Solea senegalensis. Histol. Histopathol. 11, 881-888, 1996

Scocco P., Accili D., Menghi G., and Ceccarelli P.: Unusual glycoconjugates in the oesophagus of a tilapine polyhybrid. J. Fish Biol. 53, 39-48, 1998.

Uehara K., and Miyoshi S.: Microridges of oral mucosal epithelium in carp, Cyprinus carpio. Cell Tiss. Res. 251, $547-$ $553,1988$.

Vegas-Velez M.: La structure histologique du tube digestif des poisons téléostéens. Téthys 4, 163-174, 1972.

Vieira L.: Histologia e histoquimica do tubo digestivo e órganos anexos de pós-larvas e juvenis de Solea senegalensis (Kaup, 1858) alimentados com diferentes dietas. Relatório de estágio do curso de Licenciatura em Biologia Marinha e Pescas. Univ. do Algarve. Faro. Portugal, 2000.

Watrin A., and Mayer-Gostan N.: Simultaneous recognition of ionocytes and mucous cells in the gill epithelium of turbot and in the rat stomach. J. Exp. Zool. 276, 195-101, 1996.

Weinreb E.L., and Bilstad N.: Histology of the digestive tract and adjacent structures of the rainbow trout, Salmo gairdneri irideus. Copeia 3, 194-204, 1955.

Wu A., Csako M., and Herp A.: Structure, biosythesis, and function of salivary mucins. Mol. Cell. Biochem. 137, 39-55. 1994.

Yamamoto M., and Hirano T.: Morphological changes in the esophageal epithelium of the eel, Anguilla japonica, during adaptation to sea water. Cell Tiss. Res. 192, 25-38, 1978.

Zaccone G., Fasulo S., and Licata A..: Ultrastructural demonstration of alkaline phosphatase (ALP) and $\mathrm{K}^{+}$-p-nitrophenyl phosphatase $\left(\mathrm{K}^{+}\right.$-p-NPPase) in the epidermal ionocytes of Blennius sanguinolentus. Histochem. 81, 47-53, 1984.

Zimmer G., Reuter G., and Schauer R.: Use of influenza cvirus for detection of 9-o-acetyled sialic acids on immobilised conjugates by esterase activity. Eur. J. Biochem. 204, 209-215, 1992 